\title{
Nurses' Stress and Anxiety in Acute and Intermediete Ward at Mental Health Hospital Riau
}

\author{
Nelvica Salny', Eka Malfasari \\ ${ }^{1,2}$ STIKes Payung Negeri Pekanbaru
}

\begin{abstract}
Psychiatric health nurses work with patients who experience ineffective coping mechanisms for the illness they are experiencing. This makes psychiatric nurses often deal with patients who show different types of symptoms with behavioural problems such as violence, assault, and suicide when hospitalized for anxiety and stress for nurses. The purpose of this study was to determine the difference of anxiety level and stress on nurses in acute room and intermediate room. The type of this study was quantitative with comparative analytic design using cross sectional study approach. The sample in this study were 19 acute room nurses and 90 intermediate room nurses. This research was conducted in April 2018 in the treatment room at RSJ Riau Province. The measuring tool used the DASS 42 questionnaire using anxiety and stress questionnaires. The analysis used univariate and bivariate analysis using independent $t$ test statistic for stress variable and Mann Whitney Test for anxiety variable. The results of this study showed there was no difference in the level of anxiety on the nurses in the acute room and intermediate room seen from $\mathrm{p}$ value of $0.952(>0.05)$. And there is a difference of stress level on nurses in acute room and intermediate room seen from $p$ value $0,000(<0,005)$. Based on the results of this study, nurses are expected to recognize the response level of anxiety and stress experienced by nurses.
\end{abstract}

Keyword: nurse, anxiety, stress, acute ward, intermediate ward.

Received 04 February 2019| Revised 14 May 2019| Accepted 26 January 2019

\section{Introduction}

The nurse does not only work in the general health department but also in psychiatric health. Psychiatric health nurses work with patients who experience the ineffectiveness of coping mechanisms for their illness. This makes psychiatric nurses often face patients who display various types of symptoms with behavioral problems such as violence, attacks, and suicide when hospitalized which can cause anxiety and stress for nurses. Long-term exposure to stress work experienced by nurses will cause mental nurses to suffer from stress responses and symptoms of depression (Wang et al. 2014). According to the study (Elita, 2013) of 61 nurses who worked in the care room of the Riau Provincial Hospital about the incidence of acts of

\footnotetext{
*Corresponding author at: Jl. Prof.Maas No. 03 Kampus USU, Medan, Indonesia 
violence by mental inpatients, physical violence carried out by patients on their own (84\%), verbal violence grumbling (70\%), verbal violence in the form of threats to nurses (65\%), violence in the form of humiliation to nurses (77\%), passive violence such as refusing to take medication, eating and drinking (59\%), violence in the form of physical threats to nurses $(79 \%)$, destructive violence environment (54\%), physical violence which caused minor injury (66\%), physical violence that caused serious injury (20\%), attempted suicide (33\%), sexual temptation (64\%). The data above states that nurses are vulnerable to trauma from violent behavior by patients. The behavior problem of patient violence almost always occurs in the mental care ward. Violent behavior is one of the threats to the physical and psychological health of nurses. Nurses tend to be victims in the incidence of client violence behavior. Nurses must face violence both verbally and physically which occurs almost every day. Violent behavior carried out by patients will have fatal consequences for both nurses and patients. If this pressing situation is not immediately addressed, it does not rule out the possibility of creating stress and conflict on nurses (Elita, 2013). Psychiatric nurses are people who are often targeted and involved in the aggression of patients. From the results of the study (Foster, Bowers, \& Nijman, 2007) obtained results from 254 recorded aggression events, nurses are the people most often targeted in the event of aggressive behavior that is as much as $(57.1 \%)$. The most frequent cause of aggressive action is patients who leave the ward by (29.5\%). The most common form of violence done by patients is oral aggression $(60 \%)$. The most commonly used form of intervention to deal with aggressive behavior was oral intervention (43.7\%) and confinement interventions carried out as much (25\%) (Foster et al., 2007). This does not rule out the possibility to cause anxiety and stress for psychiatric nurses

The results of the study (Azalia, Saragih, \& Idayati, 2017) showed that nurses who had received aggressive behavior from patients experienced stress. Nurses who get aggressive behavior from patients experience mild stress $50.5 \%$, moderate stress $19.8 \%$. In addition, anxiety also often occurs in nurses in the treatment ward. According to research (Isriyadi, Istiningtyas, \& Safitri, 2015), anxiety will always occur in nurses in the acute ward because of verbal threats of abuse or physical violence. Nurses who served in the acute ward of the Mental Hospital, experienced mild anxiety $51.6 \%$, moderate anxiety $29.0 \%$. The inpatient care ward at Tampan Hospital in Riau Province is an acute psychiatric treatment ward and an intermediete care ward. Acute psychiatric treatment ward, is a treatment ward for patients with acute psychiatric conditions. These acute psychiatric conditions include actions that endanger one and others, disturbances in thoughts, feelings and actions where immediate therapeutic intervention is needed (Davies, 2009).

Most patients who are treated in the acute ward due to decreased behavior and mental condition. There were $34(46.6 \%)$ who were there as a result of threatened or actual physical violence against others, $11(15.1 \%)$ due to relapse of psychotic symptoms, $10(13.7 \%)$ due to selfinjurious behavior, and $11(15 \%)$ due to property damage or socially unacceptable behavior. 7 admissions (9.6\%) were not related to mental behavior or abnormalities. In 4 of the cases entry into the acute room occurred due to lack of availability of beds elsewhere in the unit. In 3 other 
cases the patients were pregnant and considered inappropriate to be placed in the main ward (Dolan \& Lawson, 2014). Many effects that occur on nurses due to decreased behavior and mental conditions in the psychiatric ward. One of the effects of anxiety and stress on nurses. anxiety will always occur in nurses in the acute ward, both for nurses who have long and new work periods, because verbal threats of abuse, physical violence, and work stressors occur all the time, not only in the early years of work or the final years of work. The cause of anxiety experienced by nurses is because the workload is too heavy, where nurses must take nursing actions in very acute mental patients, with the characteristics of acute psychiatric patients namely attacking and threatening other people (dramatic admission), the condition of patients who often make disputes with protest against nursing staff with the aim of refusing treatment and treatment to be carried out (Salzmann-eronson, Lützén, Ivarsson, \& Eriksson, 2008). Then the intermediete care room is a care room for mentally ill patients but still requires close supervision. Patients entering the psychiatric inpatient unit are generally in a crisis situation as well as their self-defense mechanisms that are less effective so that during this period, action attack or violence can occur. Actions such as escape, suicide, substance use / alcohol, refusal of treatment, and detention can occur at any time in the intermediate care room which will cause anxiety, stress, and alertness for nurses (Bowers, 2014).

Based on interviews of researchers conducted in February with 4 nurses in the Intermediete Room, 2 people (50\%) nurses stated that they had experienced verbal violence in the form of threats and insults from clients and 1 person $(25 \%)$ had experienced physical violence from patients. , then 1 person (25\%) nurses did not experience violence from patients. This is one of the physical and psychological Ahealth threats for nurses. And nurses also expressed anxiety in intervening on their own when entering into the treatment ward which is key because of anxiety the client will commit violent behavior to the nurse. Based on these phenomena researchers are interested in examining whether there are differences in the level of anxiety and stress in nurses in the acute room and intermediates.

\section{Research Methods}

This type of research uses a type of quantitative research with comparative analytical research design using a study cross sectional approach. In a icross-sectional study where subjects were observed only once through measurement or observation at the same time (Notoatmodjo, 2012). In this study, the design used aims to determine the differences in anxiety and stress levels of nurses in acute and intermediete ward. The type of this study was quantitative with comparative analytic design using cross sectional study approach. The sample in this study were 19 acute ward nurses and 90 intermediate ward nurses. This research was conducted in April 2018 in the treatment room at RSJ Riau Province. The measuring tool used the DASS 42 questionnaire using and stress questionnaires. The analysis used univariate and bivariate analysis using independent $\mathrm{t}$ test statistic for stress variable and Mann Whitney Test for anxiety variable anxiety 


\section{Research Result}

The result of this study are conducted below:

Table 1. Nurses' based on Ages dan Lenght of Occupations in Acute and Intermediate Ward

\begin{tabular}{l|l|l|l} 
Variabel & Mean & SD & $\begin{array}{l}\text { Minimum- } \\
\text { Maximum }\end{array}$ \\
\hline Age & 33,87 & 7,75 & $21-53$ \\
\hline $\begin{array}{l}\text { Lenght of } \\
\text { Occupation }\end{array}$ & 8,04 & 7,6 & $1-35$
\end{tabular}

Based on table 1, the data shows that the average age of respondents is 33 years. With a minimum age of 21 years and a maximum age of 53 years. The data above can also be seen that the average length of work of nurses is 8 years, with a minimum working period of 1 year and a maximum length of work is 35 years.

Table 2. Nurses' Based on Education and Position in Acute and Intermediate Ward

\begin{tabular}{l|l|l|l|l} 
No & Variabel & & Frequency & Percentage \\
\hline 1 & \multirow{2}{*}{ Position } & Head Nurse & 7 & $6,4 \%$ \\
\cline { 4 - 5 } & & & & \\
\cline { 4 - 5 } 2 & & Leader Nurse & 9 & $8,3 \%$ \\
\cline { 4 - 5 } 3 & & Nurse & 93 & $85,3 \%$ \\
\hline 1 & \multirow{2}{*}{$\begin{array}{l}\text { Tingkat } \\
2\end{array}$} & Pendidikan & 1 & $9 \%$ \\
\cline { 4 - 5 } & & Diploma & 57 & $52,3 \%$ \\
\cline { 4 - 5 } & Bachelor & 31 & $28,4 \%$ \\
\cline { 3 - 5 } & Bachelor + Profesion & 20 & $18,3 \%$ \\
\hline 4 & & 109 & $100 \%$
\end{tabular}

Based on table 2, the majority of respondents were educated D3 as many as 57 people $(52.3 \%)$. the majority of respondents were nurses implementing as many as 93 people (85.3\%).

Tabel 3. Nurses based on Level of anxiety and Stress

\begin{tabular}{l|l|l|l|l}
\multirow{2}{*}{ Variabel } & Mean & P Value & $\mathbf{N}$ \\
\cline { 2 - 5 } & Acute & Intermediete & & 109 \\
\hline Anxiety & 55,39 & 54,92 & 0,952 & 109
\end{tabular}

From the results of table 3 analysis it can be seen that the variable level of anxiety using the Mann Whitney Test and stress levels using the Independent $t$ Test. The average value of anxiety levels in acute room nurses is 55.39 and the average value of anxiety levels for intermediate rooms is 54.92. At the level of anxiety obtained by the value of $p$ value is 0.952 greater than the value of 0.05 , thus Ho is accepted, which means there is no difference in the level of anxiety in nurses in the acute room and intermediate rooms in RSJ Riau Province. The average value of stress levels in acute room nurses is 15.00 and the average stress level of nurses in intermediete 
rooms is 8.67. At the stress level the value of $p$ value is 0,000 less than 0.05 , thus Ho is rejected which means there are differences in stress levels in nurses in acute rooms and intermediete rooms in RSJ Riau Province.

\section{Research Discussion}

The results of this study indicate that nurses who work in the care room at the Riau Provincial General Hospital are 33 years old on average. the nurse is at least 21 years old and a maximum of 53 years old. According to Erikson dalam (Upton, 2012), ages 19 to 40 years are early adulthood, where in early adulthood a person begins to separate from family, get married, work, and have children. At this time a person can experience stress related to marital problems, work, and also parenting. According to research (Ratih \& Suwandi, 2013), in work shows that the older a person is, the more likely the tendency to work stress will be. The younger the fewer the number of respondents detected have work stress. This can be seen from the level of work stress. most experienced by workers who are in the middle adult age category. Based on the results of the existing research and theory according to the analysis (Arisandy, 2018), it can be seen as for age having a close relationship with various characteristic traits towards others. Thus it can be understood that the existence of differences in experience according to age has a meaning (influence) related to anxiety.

The results of this study indicate that the majority of nurses are female as many as 65 respondents with a percentage $(59.6 \%)$ and 44 respondents $(40.4 \%)$ male sex. Every male and female individual has the same opportunity to experience anxiety and stress in his life. The link between sex and anxiety and stress directly is still unclear. According to research (Dwi, 2005), found that gender differences with work, where women experience stress as well as men. The difference in male stress conditions with women is that women face more stressors from family and work environments. Married female nurses and children have more severe roles and responsibilities than single female nurses.

The dual role was also experienced by the female nurse because in addition to acting in the family, the female nurse also played a role in her career. Career women who are faced with many jobs are usually more stressed than men. According to research (Goretti, 2007), it was proven that there was no difference in the level of anxiety in dealing with patients in mental hospitals between male and female nurses. Gender differences and roles between men and women do not make men and women's anxiety levels different when dealing with patients in mental hospitals. The absence of 
differences in the level of anxiety in dealing with patients between male nurses and female nurses in mental hospitals can be caused by the length of the nurse's work experience in dealing with patients. This can happen because in general nurses who work on average are already senior and many work over 5 years. This means that female nurses are used to their duties as nurses in psychiatric hospitals whose job it is to care for patients with unstable mental conditions so that the anxiety that arises is not too high. In this study showed that the majority of nurses' education in the care room at Riau Provincial Hospital namely D3 were 57 respondents with a percentage (52.3\%). Nurse's knowledge and skills are very important in carrying out nursing duties. Job anxiety and stress will occur when existing abilities are not comparable to the demands of the job. It can be said that the level of knowledge and education has an important role in anxiety and stress. With the knowledge and education possessed by a nurse will be able to communicate effectively. The research conducted (Ummamah, 2012) related to the level of education and its effect on stress which found that education levels, years of service, and workload influence the stress of nurses.

In the study (Arisandy, 2018), it shows that the higher the education of a person the more the anxiety level of the nurse decreases in dealing with patients with nervous anxiety. Education aims to develop and expand individual knowledge, experience and understanding. The higher a person's education, the easier it is for someone to think broadly, the higher the initiative, and the easier it is to find efficient ways to get the job done well (Ratih \& Suwandi, 2013). The results of this study indicate that the average length of work of nurses is 8 years. With a minimum working period of 1 year and a maximum working period of 35 years. The working period has the potential for work stress. This is in accordance with Robbin's opinion based on the theory of the inverse U relationship pattern that reacts to stress over time and to changes in stress intensity, both short and long periods of work can trigger work stress and are exacerbated by a large workload (Septian \& Ernawati , 2014). According to research (Damayasa, 2018) shows that there is a relationship between the length of work with nurse anxiety levels. Long service life will result in more experience than new ones, so it is not so awkward with the threats and the risk of experiencing less anxiety. Cristami and Wardaningsih (2016) in (Yanti, Nauli, \& Utomo, 2017) say that the more work experience they have, will help them give an attitude towards patients. This can happen because experience does not only focus on time but also because of the real situation of a case where the nurse can learn new things from the patient they are caring for.

The results of this study indicate that the functional positions of nurses in the care room at Riau Provincial Hospital consist of 7 respondents with a percentage (6.4\%) of 
positions as Head of Room, 9 respondents with a percentage (8.3\%) of Team Leader positions, and 93 respondents with a percentage (85.3\%) as Implementing Nurses. Nursing services is one part of the main services in hospitals has a significant influence on the quality of hospital services (Gillies, 1998) in (Priyodwi, 2008). Competition that develops and pressures on organizations to be more productive forces a hospital organization to make new strategies in an effort to increase productivity and the impact of these conditions to make people involved in organizations including nurses under the pressure of work that can cause work stress (Priyodwi, 2008). According to the results of this study, the average nurse anxiety level is within normal limits. Normal anxiety is a reasonable response to events that are being experienced. This anxiety does not experience pressure, but gives motivation to change to a better direction. Someone who experiences this does not need therapy because it is beneficial in his life (Corey, 2013). Normal anxiety can be a source of motivation for progress, but if experienced in excess, it can interfere with self-stability and balance in life. People who experience anxiety can feel disturbances in themselves, such as anxiety, tension, fear, sweating and so on. Anxious person feels himself confined and far from freedom, so there is a desire to get out of that anxiety. Many do not realize that creative ideas can be blocked by excessive anxiety before the idea reaches the level of consciousness. Therefore, anxiety must be controlled (Hayat, 2014).

According to the results of this study, the average nurse stress level is within normal limits. Normal stress is faced regularly and is a natural part of life such as in situations of fatigue in doing tasks, feeling the heart beat beating harder after activity. Natural normal stress and become important, because everyone must have experienced stress. In addition, nurses also experience stress levels in the category of moderate stress and moderate stress. Mild stress is a stressor that is dealt with regularly which can last several minutes or hours. A situation like this sleeps a lot, forgets, jams, is criticized. This stress stage is classified as stage I stress. This stage is the lightest stage of stress and is usually accompanied by feelings of enthusiasm for working big, over (over acting), sharp vision not as usual, feeling able to complete work more than usual, but without realizing that energy reserves are running low (Hawari, 2010).

From the results of research using the Mann Withney Test statistical test, the $\mathrm{p}$ value is 0.952 greater than 0.05 , thus Ho is accepted, so it can be concluded that there is no difference in the level of anxiety in nurses in the acute room and intermediete rooms in RSJ Riau Province. This study is not in line with the research (Setiawati, 2011), there is a difference in the level of anxiety between HCU nurses and regular inpatient nurses. This shows that nurse anxiety is different in each room. 
According to the results of this study, there were no differences in the level of anxiety in acute room nurses and intermediate rooms. According to the analysis of researchers, this can be influenced by the length of time the nurses work in the treatment room. Nurses who work in the care room at the Riau Provincial Hospital have an average length of work of 8 years, which is classified in the long term work category. This research is in line with the research (Damayasa, 2018) showing that there is a relationship between the length of work and the anxiety level of nurses. Long service life will result in more experience than new ones, so it is not so awkward with the threats and the risk of experiencing less anxiety. Events that initially cause a person to worry more and more will feel normal so that the level of anxiety decreases (Nursalam, 2008).

The duration of work shows how long someone works for each job or position (Siagian, 2008). Duration of work is the experience of someone who will determine growth in work and position. The longer the working period, the more experience that contributes in providing work services according to applicable standards or procedures. Someone who works long time will tend to feel at home and comfortable in his work environment, because he has gone through an adaptation process (Aknaria, Panjaitan, \& Hariyani, 2015).

In addition, nurses have previously passed through the educational process that forms them so that they are in a condition ready to face nursing tasks. Difficulties and obstacles they will still find, but the belief that someone can complete a task does not automatically eliminate the difficulties or obstacles that may arise, self-confidence that encourages a harder effort to overcome all difficulties and make individuals able to face and solve problems without emotional stress so that it can eliminate the anxiety that arises when working against psychiatric patients (Ambarwati, 2003) in (Goretti, 2007).

Based on several studies about the level of anxiety that has been described, the researchers argue there is no difference in anxiety in each place / room. Nurse anxiety is within the limits of normal anxiety. Nurses who work in acute care rooms and intermediate rooms have an average length of work. This makes nurses accustomed to dealing with mental patients and nurses already have a lot of experience so they are no longer awkward in dealing with mental patients. And coupled with the training followed by nurses.

On the stress level variable using the independent $t$ test, the $p$ value is 0,000 less than 0.05 , thus Ho is rejected which means that there are differences in stress levels in nurses 
in acute rooms and intermediate rooms in RSJ Riau Province. Stress on nurses varies, besides individual characteristics that might affect someone facing stress, nurses also experience stress caused by their activities in caring for patients. The level of work stress based on workplace / care room seems to vary. This is according to the opinion that states that psychiatric nurses who work with patients with severe mental disorders have a high mental burden (Juwita, Sedyowinarso, \& Nurjannah, 2008).

According to the results of this study, the stress level of nurses is different in each ward. In this study the average stress level of acute room nurses was higher than that of intermediate room nurses. According to the analysis of researchers, this can be influenced by the condition of patients who are in an acute room that is severe and has a high level of violence. This study is in line with the research (Setiawan, 2015), nurses who work in acute psychiatric rooms are nurses who work in care units that provide services to patients with acute psychiatric conditions with characteristics of patients who have the potential to endanger themselves and others. There are four categories of patients in the acute psychiatric room how to enter dramatically into dramatic admission, protest and refusal (protest and refusal of treatment), increased behavior (escalating behavior), and the existence of temporary temporary rules coercive measure). Research conducted by Sullivan, in (Konstantinos \& Christina, 2008), about work stress psychiatric nurses found that violent behavior, and observation of patients with potential suicide, were the most frequent causes of stress on psychiatric nurses. While Trygstat's research in (Konstantinos \& Christina, 2008), found that the problem or cause of stress in psychiatric nurses is one of the problems in treating patients, especially patients who are chronic and recidivism. Acute psychiatric patients usually come brought by security officers or police officers because of threatening other people (dramatic admission). Another characteristic of acute psychiatric patients is the condition of patients who often conduct disputes by protesting against staff nurses with the aim of refusing to take care and treatment (protest and refusal treatment). In some circumstances patients with violent behavior cannot be invited to communicate. Patients sometimes shout threatening, and mock or insult using harsh words to officers and other patients (escalating behavior). This threatening and attacking behavior is sometimes not only aimed at other people but also the patient's own rice, this self-destructive behavior if accumulated will lead to suicidal behavior (Salzmann-erikson et al., 2008). 


\section{REFERENCES}

[1] Aknaria, Panjaitan, F., \& Hariyani. (2015). Pengaruh Masa Kerja Dan Keselamatan Kerja Terhadap Kinerja Karyawan. Jurnal Ilmiah Progresif Manajemen Bisnis STIE- IBEK Volume 2.1.

[2] Arisandy, W. (2018). Karakteristik perawat dengan tingkat kecemasan dalam mengatasi pasien gaduh gelisah di rumah sakit ernaldi bahar sumatera selatan, $X V I(1)$

[3] Azalia, R., Saragih, J., \& Idayati, R. (2017). Hubungan Perilaku Agresif Pasien dengan Stres Perawat Rumah Sakit Jiwa Aceh, 2, 55-60.

[4] Bowers, L. (2014). Safewards: A new model of conflict and containment on psychiatric wards. Journal of Psychiatric and Mental Health Nursing, 21(6), 499-508. https://doi.org/10.1111/jpm.12129.

[5] Corey, G. (2013). Theory and Practice of Conseling and Psychotherapy. Belmont: Brooks/Cole.

[6] Damayasa, C. A. P. (2018). Hubungan Lama Kerja Dengan Tingkat Kecemasan Tenaga Keperawatan Dalam Menghadapi Pasien Rawat Inap Di Rumah Sakit Graha Yogyakarta.

[7] Davies, T. (2009). ABC Kesehatan Mental. jakarta: EGC.

[8] Dolan, M., \& Lawson, A. (2014). A psychiatric intensive care unit in a mediumsecurity unit. Journal of Forensic Psychiatry, 12(3), 684-693. https://doi.org/10.1080/095851801100571, 45

[9] Dwi, H. (2005). Stres dI Tempat Kerja: Perbandingan Antara Gender Dengan Pekerjaan, 31-40

[10] Elita, V. (2013). Persepsi perawat tentang perilaku kekerasan yang dilakukan pasien di ruang rawat inap jiwa, 31-40.

[11] Foster, Bowers, \& Nijman. (2007). aggresive behaviour on acute psychiatric wards: prevalence, severity and management.

[12] Goretti, Y. E. S. M. (2007). Perbedaan Tingkat Kecemasan Perawat Pria Dan Wanita Menikah Dalam Menghadapi Pasien Di Rumah Sakit Jiwa.

[13] Hawari, D. (2010). Psikiater Manajemen Stress, Cemas dan Depresi. Jakarta: FKUI.

[14] Hayat, A. (2014). Kecemasan dan Metode Pengendaliannya, XII, 01

[15] Isriyadi, B., Istiningtyas, A., \& Safitri, W. (2015). Hubungan Masa Kerja Dengan Tingkat Kecemasan Perawat Di Ruang Akut Rumah Sakit Jiwa Daerah Surakarta. 
[16] Juwita, Sedyowinarso, M., \& Nurjannah, I. (2008). Faktor-Faktor yang Mempengaruhi Tingkat Stres Kerja Perawat Psikiatri Di Rumah Sakit Jiwa Provinsi Kepulauan Bangka Belitung, 03

[17] Kaplan, H. ., \& Sadock, B. . (2014). Buku Ajar Psikiatri Klinis Edisi 2. Jakarta: EGC.

[18] Konstantinos, N., \& Christina, O. (2008). Factors Influencing Stress and Job Satisfaction of Nurses Working In Psychiatric Units : A Research Review, 4, 183-195.

[19] Notoatmodjo, S. (2012). Metodologi Penelitian Kesehatan. Jakarta: Rineka Cipta.

[20] Nursalam. (2008). Konsep Dan Metode Keperawatan edisi 2. Jakarta: Selemba Medika.

[21] Priyodwi, M. B. (2008). Hubungan Faktor Individu Dan Organisasi Rumah Sakit Dengan Stres Kerja Serta Hubungan Stres Kerja Dengan Kinerja Asuhan Keperawatan Perawat Pelaksana Di Ruang Rawat Inap RSUD dr.Soegiri Lamongan, 1(September), 1-12

[22] Septian, Y. K., \& Ernawati, D. (2014). Faktor- Faktor yang Berhubungan dengan Stres Kerja pada Perawat di Rumah Sakit Jiwa Daerah Dr.Amino Gondohutomo Semarang 2014.

[23] Setiawan, S. N. (2015). Hubungan perilaku agresif pasien dengan stres perawat di psikiatri intensive care unit (picu) rsjd surakarta.

[24] Siagian, S. P. (2008). Manajemen Sumber Daya Manusia. Jakarta: Bumi Aksara.

[25] Sudarma, M. (2008). Sosiologi untuk kesehatan. Jakarta: Selemba Medika.

[26] Ummamah, U. (2012). Pengaruh Tingkat Pendidikan, Masa Bekerja dan Beban Kerja Terhadap Tingkat Stres Perawat Di Rumah Sakit Jiwa Pemerintah Aceh.

[27] Upton, P. (2012). Psikologi Perkembangan.Jakarta: Erlangga.

[28] Wang, S. M., Lai, C. Y., Chang, Y.-Y., Chiung- Yu Huang d, J., Zauszniewski, \& Yu, C.- Y. (2014). Hubungan antara Stres Kerja, akal, dan Depresi Tingkat di perawat psikiatri. Retrieved from rice921@yahoo.com.tw (SM Wang), chienlai@ntunhs.edu.tw (CY Lai), m685001@kmu.edu.tw (Y. -Y. Chang), chyh@isu.edu.tw (C.-Y. Huang), jaz@case.edu (JA Zauszniewski), cyyu@kmu.edu.tw (C.-Y. Yu 